International Journal of Health Sciences
Available online at www.sciencescholar.us
Vol. 6 No. 1, April 2022, pages: 137-148
e-ISSN: 2550-696X, p-ISSN: 2550-6978
https://doi.org/10.53730/ijhs.v6n1.3527

\title{
Healthy Living Culture as Management of Tuberculosis
}

\begin{abstract}
CrossMark
Supriyanto a, Masrukhi ${ }^{b}$, Suyahmo c , Tri Marhaeni Puji Astuti d

Manuscript submitted: 2 September 2021, Manuscript revised: 9 December 2021, Accepted for publication: 1 January 2022

Corresponding Author ${ }^{\text {a }}$

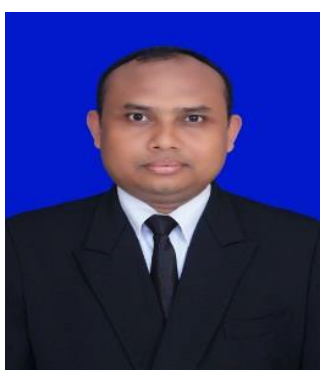

Keywords

behavior;

disease management;

healthy body;

healthy culture;

\section{Abstract}

The aim of this research is to examine the concept of a healthy living culture that exists in the Semarang city community in the management of tuberculosis. The forms of healthy culture management, strengthening aspects of public education to build awareness of a healthy living culture (living in a clean environment, not smoking, exercising enough, eating enough fruits and vegetables), and eliminating negative stigma against people with tuberculosis. The culture of healthy living carried out by the people of Semarang City is carried out in the form of 1). Implement healthy living behaviors such as; living in a clean environment, do not smoke, exercising enough, eat enough fruit and vegetables. 2). Availability of health facilities that are professional and easily accessible to the public such as hospitals and health centers 3). Remove the negative stigma against people who are sick with tuberculosis. Healthy living culture is part of the complexity of cultural elements and is also a concept of life by prioritizing various life activities based on healthy actions.
\end{abstract}

social adaptation;

spiritual health;

tuberculosis;
International Journal of Health Sciences (C) 2022. This is an open access article under the CC BY-NC-ND license (https://creativecommons.org/licenses/by-nc-nd/4.0/).

\section{Contents}

Abstract.

1 Introduction

2 Materials and Methods

3 Results and Discussions

Conclusion

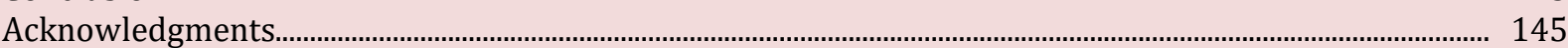

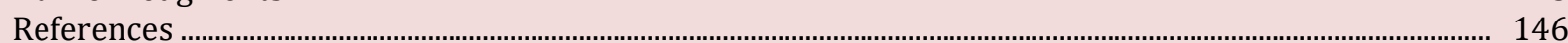

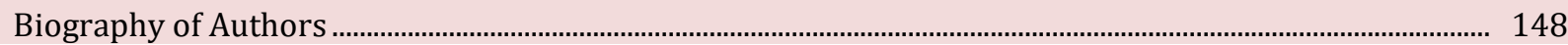

${ }^{a}$ Universitas Negeri Semarang, Semarang, Indonesia

b Universitas Negeri Semarang, Semarang, Indonesia

c Universitas Negeri Semarang, Semarang, Indonesia

${ }^{d}$ Universitas Negeri Semarang, Semarang, Indonesia 


\section{Introduction}

The concept of a healthy culture is part of health anthropology which doctors view as a biocultural discipline that pays attention to the biological and socio-cultural aspects of human behavior, especially about how interactions between them throughout the history of human life affect health and disease (Foster \& Anderson, 2006). Understanding culture according to Kroeber \& Kluckhohn (1952), is "an abstraction of concrete human behavior, but it is not the behavior itself". Furthermore, Linton (1936), said that culture itself is intangible and cannot be directly appreciated even by the individuals who participate in it. In line with this, Radclife-Brown, (1940), states that the word culture "indicates, not concrete reality, but an abstraction, and as is commonly used a vague abstraction". It is said that culture is the name we give to some behavior of some individuals, the selection is done arbitrarily and made according to subjective criteria (White, 1959).

Culture is the overall pattern of understanding or meaning in historically transmitted symbols; a system of inherited conceptions in the form of symbolic forms by which humans communicate, preserve and develop their knowledge and attitudes toward life (Geertz, 1973). Others argue that culture influences action not by assigning ultimate values toward which action is oriented, but by shaping the repertoire or "equipment" of habits, skills, and styles from which people construct "action strategies," (Swidler, 1986). Meanwhile, Koentjaraningrat (2009), argues that culture is "the whole system of ideas, actions and human creations in people's lives that are made into the human property by learning". Based on the above opinion, it can be concluded that culture is the entire system of ideas, actions, and human creations accompanied by a comprehensive pattern of understanding or meaning in historically transmitted symbols and has a conceptual system to be able to preserve and develop knowledge of human attitudes and behavior (Dantzer \& Kelley, 2007; Kelley et al., 2003; Benjamini et al., 2001). Meanwhile, according to WHO (1981), healthy is "a state of complete physical, mental and social wellbeing". Healthy is not only about the physical condition, but also includes the mental and social conditions of a person. According Fialkowski et al. (2014), the children's healthy living program that involves the community can be done by promoting healthy eating and physical activity policies, training and supporting role models, increasing access to fruits, vegetables, water, and safe games, and providing education/training.

Based on the description above, a healthy living culture can be defined as a pattern of human behavior that develops intending to obtain physical, mental, and spiritual health that allows a socially and economically productive life and can carry out daily activities with passion. Healthy living culture is a concept of life that puts forward healthy efforts and activities.

The importance of a healthy culture is to maintain a healthy body and also to get a better life. Another benefit of running a healthy culture is to get stable physical and mental health (Lee et al., 2003; Schubert, 2015). In addition, there are also benefits that we can get from running a healthy lifestyle, both physically and mentally. In addition, running a healthy lifestyle will also make us feel happier so that our quality of life increases. Measures of healthy living behavior as part of a healthy living culture are part of cultural elements. Humans need culture, in which there is an ethical element, to be able to maintain survival. Cultured humans are humans who maintain the rules of life.

As Karso \& Wibawa (2017), said the disease has a social and economic impact on society. Therefore, the cultural approach can be used as an alternative in the management of tuberculosis, as part of a comprehensive effort to manage the disease, in addition to the health approach (Carter et al., 2010; Westwood \& Barker, 1990).

According to Astuti \& Ardiato (2010), the high findings of pulmonary tuberculosis sufferers can be caused by feelings of shame from sufferers and their families as well as negative stigma from the surrounding community. For that, in the management of tuberculosis, a good service system is needed. Samavor et al. (2014), states that a competent health care system consists of interrelated components that (1) recognize the importance of culture, (2) provide an assessment of intercultural relationships, (3) maintain awareness of the dynamics caused by cultural differences, (4) complement cultural knowledge, and (5) adapt it to meet patient needs. The system also recognizes the integration and interaction of beliefs and behaviors regarding health, the causes and spread of disease, and the outcomes of treatment for a given culture. 


\section{Materials and Methods}

This qualitative research used the phenomenological analysis method. Creswell (2010), explains phenomenological approach identifies human experience nature on the certain phenomenon. Understanding the experiences of human life makes the philosophy of phenomenology a research method whose procedures require researchers to study many subjects by being directly involved and relatively long in them to develop patterns and relationships of meaning.

The research method uses a qualitative approach. The research subjects were 14 people consisting of 5 key informants, 4 main informants, and 5 additional informants. Key informants are people who are sick with tuberculosis, the main informants are people who have recovered from tuberculosis and additional informants are family or health cadres who accompany the patient's treatment (Frieden \& Driver, 2003; Maher, 2003; Bhardwaj et al., 2009).

\section{Data collection technique}

The collection of data and information in this study was carried out in various ways and techniques from various sources. Data collection techniques in scientific research are qualitative data collection techniques, including observation, documentation, and interviews:

- Observation

Observations or observations made in this study were used to observe all activities of tuberculosis patients, recovered patients in Semarang City spread over several regions, namely: 1). Kemijen Village, East Semarang District, 2). Pelombokan Village, North Semarang District, 3). Tlogosari Kulon Village, Pedurungan District and 4) Bangetayu Wetan Village, Genuk District. Observation activities were carried out at the beginning of the study as a step to identify problems in the field. After the observations are made and get the problems that exist in the field, the next stage is conducting research. The tools used in the observations include tape recorders, observation sheets, field notes.

- Documentation

Documentation is used as additional data to strengthen the results of observations that have been made. The data are in the form of activities for tuberculosis patients, cured patients, and community activities in the Districts of East Semarang, North Semarang, Pedurungan, and Genuk, Semarang City.

- Interview

Face-to-face interviews were conducted directly between the researcher and key and key informants in the Districts of East Semarang, North Semarang, Genuk, and Pedurungan. Interviews were conducted in February, August, September, and October 2020. The instruments used were interviews and recordings using mobile phones. This interview was conducted to key informants as many as 5 tuberculosis patients, main informants 4 recovered patients, and 5 health cadres/families located in four subdistricts.

The researchers used the interactive analysis model of Miles et al. (2014), see the following figure:

Supriyanto, S., Masrukhi, M., Suyahmo, S., \& Astuti, T. M. P. (2022). Healthy living culture as management of tuberculosis. International Journal of Health Sciences, 6(1), 137-148. https://doi.org/10.53730/ijhs.v6n1.3527 


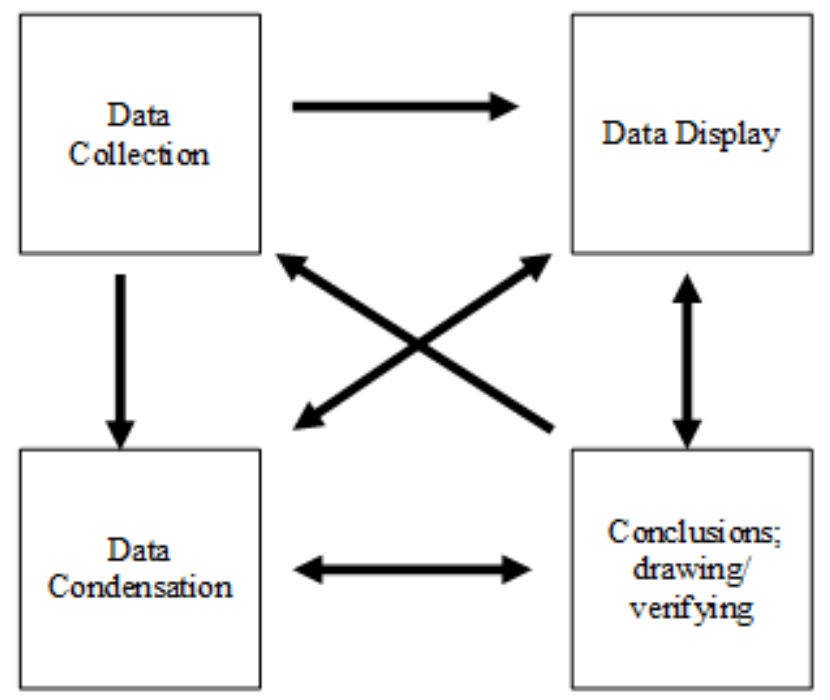

Figure 1. Interactive analysis schematic drawing

Miles et al. (2014), analysis includes: data condensation, data display, and conclusion. Here are the steps of the analysis:

- Data Condensation

In this stage, the researchers selected, focused, simplified, created abstraction, and transformed the data from written notes, interview results, or documentation. Then, the researchers compressed the data without reducing or removing some data. This process always exists in qualitative research, starting from conceptual framework, the observed case, research formulation, and data collection techniques. Then, the process continues by summarizing, coding, creating theme, categorizing, and writing memos. After completing these processes, the researchers must continue the data condensation process until the final report writing.

- Data Display

The second stage is - displaying the data. In this stage, the researchers organized and compressed the collected information. This collected information will be useful to draw conclusions. Displaying the data means facilitates research readers to understand the analysis processes. In this stage, researchers can use some viewer designs, such as tables or matrices to put certain data types and data forms for analytical activity.

- Data conclusion

The third stage is - analysis activity to draw conclusion. The nature of qualitative research is to interpret patterns, explanations, causal flows, and propositions. Thus, qualitative researchers required complete data to draw conclusion. The data collection may vary in terms of size, coding result, and applied method.

Based on the explanation above, then the data that has been collected is analyzed using various techniques, both textual and contextual. According to Astuti (2013), research results can be presented in narrative form in various ways such as descriptions, ethnography, and in-depth reflection on the behavior and management of tuberculosis in the community:

- Thematic analysis is carried out by organizing the data based on relevant themes and in accordance with the research focus. In this study also found expressions, descriptions, or explanations that stand out and are specific, so that they can provide an overview of how the life experience of the research subject, characteristics, personality, behavior, about the subject thinking about himself and his life, and conditions. Situational factors that influence their behavior. 
- Textual analysis is carried out by confirming the data from the field findings and the answers of the research subjects with the existing theories of the concept of healthy culture, so that it can be seen whether there are similarities with existing theories of healthy culture concepts, or whether there is a deconstruction of concepts and theories that gave birth to reconstruction. to finally become the definition.

- Contextual analysis is carried out by examining the data link with its external context, such as family and community in the form of values and life views.

Interpretive analysis is done by looking at the meanings contained in each data collected. The meaning can be in relation to the external context as well as the internal context.

\section{Results and Discussions}

The results of the interview with Mr. MS, he gave the following response, "Gentlemen, do you not have counseling? Yes, but Mr. Moch didn't come. Then when asked where did the TB information come from? He replied "no". Furthermore, from health cadres related to a healthy culture that is run by the community in the city of Semarang provides information that:

"Everywhere the clean and healthy lifestyle program is inferior to the second dengue fever tuberculosis program. The tuberculosis patient was sure he could recover. The identity of tuberculosis patients cannot be disclosed, unless they do not want to share their new treatment. Tuberculosis cadres alone cannot know the patient's identity. He said it violated the code of ethics. The confidentiality of the identity of a tuberculosis patient can infect others."

Based on the results of the interview above, it can provide an analysis of the culture of healthy living in an effort to manage tuberculosis in the people of Semarang City. Healthy living culture can be defined as a pattern of human behavior that develops with the aim of obtaining physical, mental and spiritual health that allows a socially and economically productive life and can carry out daily activities with passion. Findings in the field indicate that the concept of a healthy culture in the management of tuberculosis in the people of Semarang City has not gone well (Chaika et al., 2021; Exposto \& Januraga, 2021).

The informants convey information that they generally know about tuberculosis, but do not know how someone can get the disease. Their understanding is only limited if there is a relative who is sick with tuberculosis, his food is separated from the others. Mrs. NN is one of the key informants who is currently undergoing treatment for tuberculosis. He is currently 43 years old, with an elementary school education background. Her current job is as a housewife and also caring for her husband who is sick. He conveyed information that so far he has been living a clean life, for example, he often participates in community service, regulates his diet, cleans his house and his house has ventilation. Even though he was already living a healthy lifestyle, it turned out that he could contract tuberculosis, and he was surprised and asked himself why he got such a disease.

After an investigation, it turned out that his family members, namely the parents and their children, had tuberculosis. After further investigation, it turns out that when caring for a sick family member, he used to wear a mask/other protection. In addition, the attitude of his father who was sick with tuberculosis when undergoing treatment seemed to ignore his disease. This can be seen from the expression of NN's mother when she was interviewed when she said the sentence "it was the reaction when my child and father were treated. I don't know if the medicine is taken or not." This expression shows that there is a possibility of noncompliance in the treatment carried out by NN's parents so that the disease is transmitted to her (Rodnyansky et al., 2021; Permana et al., 2022).

Meanwhile, Mr. TS conveyed that his educational background was high school, and currently his job is odd, doing what he can do. His economic needs have been assisted by his son. Mr. TS has been a person who is diligent in maintaining cleanliness, besides that he is also active in community service activities to clean the environment around his residence. Including if there is counseling by PKK women sometimes she also attends.

Supriyanto, S., Masrukhi, M., Suyahmo, S., \& Astuti, T. M. P. (2022). Healthy living culture as management of tuberculosis. International Journal of Health Sciences, 6(1), 137-148.

https://doi.org/10.53730/ijhs.v6n1.3527 
Regarding his condition, which is currently sick, he said that he did not know the origin of tuberculosis. His condition was aware that at night he was often short of breath, then he was taken to the puskesmas, at that time the corona was still rampant, until there he was not immediately examined and given medicine. But after the medicine ran out, he was still short of breath, kept checking, was told to check for sputum, then the result was positive for tuberculosis.

When it was confirmed whether he was an active smoker, he said yes, but he has stopped this habit since 2012 when his wife was sick. Apart from that, his habits so far have not been a worry about a healthy living culture. The condition of his house is quite clean, he is active in community service activities and his lifestyle is quite regular. Indeed, sometimes he sleeps on the floor of the house, and even then because the air is very hot during the day. Under normal conditions he sleeps in bed and during this time he sleeps regularly, only occasionally sleeping late at night. Besides that, he has been working odd jobs so far, so his economic condition is uncertain and he is helped a lot by his children. He used to work at the Metro Hotel but has now retired. With the condition of his body that is getting older, it is really hard for him to work odd jobs. The young people's interaction and communication with the surrounding environment has been going well and there have been no problems (Hussinet al., 2021; Widana et al., 2021).

The condition of the youth's residence 3-4 years ago was prone to flooding and rob, but now the condition is good, never floods and robs again. So that it is easier for residents to clean the environment. Activities in the environment that he and his neighbours' can carry out are house cleaning, community service cleaning the environment, occasionally participating in health counselling activities by health workers, although he does not understand what the content of the counselling is for. Meanwhile, regarding his condition, which is currently ill with tuberculosis, some information is that:

- His younger brother in the village was sick with tuberculosis and his condition is now dead;

- Her second child about 10 years ago had tuberculosis. When a child is sick with food tuberculosis, glasses and plates are separated but personal protective equipment (masks) are not worn;

- When caring for a child who is sick with tuberculosis, never wear a mask to prevent transmission.

Meanwhile, the results of the interview with Mr. MS are slightly different from the condition of Mr. TS, although in it there are some similarities in the management of a healthy culture for the management of tuberculosis. Mr. MS is an adult tuberculosis patient, currently he is 63 years old. His current condition is no longer working, his daily activities include taking care of his grandchildren, while his education is only up to the second grade of elementary school. His condition is currently suffering from tuberculosis, but when asked if he has tuberculosis he does not answer frankly, but only replies that he is currently taking medicine to avoid getting sick.

Based on the statement above, Mr. MS has an open attitude or may not realize that he is sick with tuberculosis. This could be because he had just met the researcher for the first time, so he did not want to convey his openness. In addition, it could also be due to his limited knowledge about tuberculosis.

The statements from the informants above show their shock at the events they experienced. This condition can occur when a person feels unprepared with the results of the examination carried out by health workers. In addition, this condition can also be caused by the ignorance of NN's mother, TS's father and MS about the causes and symptoms of tuberculosis. Because basically tuberculosis is a disease that can cause death and in general this disease afflicts the poor and low educated. So that it becomes a burden for people who are exposed to tuberculosis. In fact, in society, people who are sick with tuberculosis, there is almost always a negative stigma from the surrounding environment (Saigal et al., 2005; Ofman et al., 2004; Barr et al., 2009).

Meanwhile, from the point of view of a healthy lifestyle, Mr. MS's condition is different from that of Mrs. NN and Mr. TS. Mr. MS has a habit of sleeping outside the house, often hanging out with his friends and staying up late at night. Mr. MS's daily activities are far from healthy culture. He wakes up at 06.30 in the morning, after that his activities are taking care of his grandchildren, and in the evening he goes out of the house to gather with his friends at the patrol post until morning. He came home only at mealtimes and baths, and so far his family had no problem with it. Mr. MS is now separated from his wife and has six children, of which only one is married. In addition, he is currently an active smoker. 


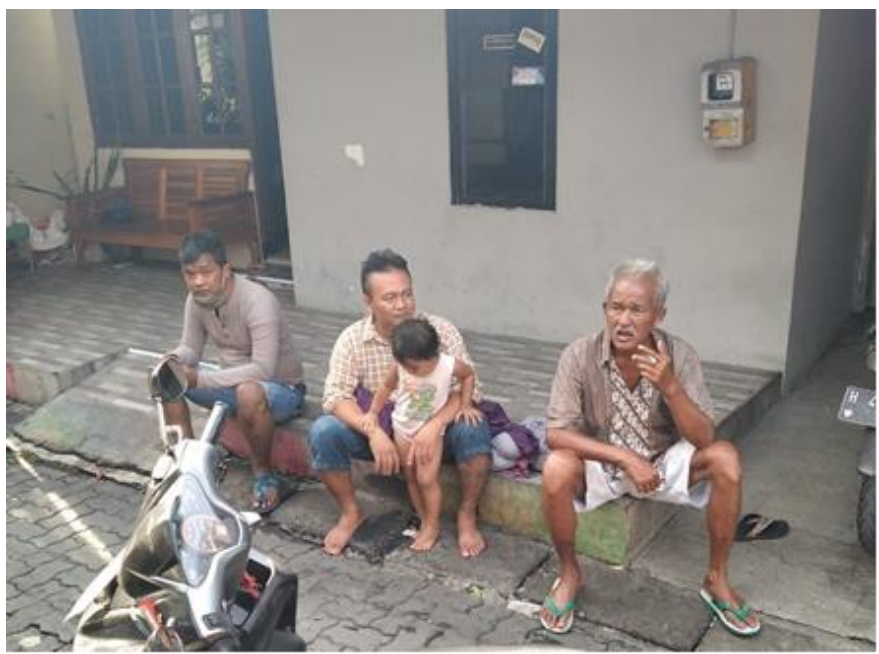

Figure 2. Activity of Mr. MS (rightmost picture) who still smokes even with tuberculosis. Source: 2020 research documentation

See figure 1.2. The above activity is the daily life of Mr. MS. He is currently sick with tuberculosis, but still can't quit smoking. According to information from his children, he is indeed difficult to take care of. Besides still smoking, Mr. MS at this time also often hangs out with his neighbors and stays up late at the patrol post. Currently he is undergoing treatment at the puskesmas accompanied by local health cadres.

Foster \& Andreson (2006), explain that socio-cultural adaptation strategies give rise to culturally based medical systems, behaviors and forms of belief, which arise in response to threats caused by disease. Attitude, qualitatively as an expression of the understanding and understanding received by someone. With the existence of a healthy living culture as a management of tuberculosis, it can be seen that, through information dissemination provided by officers who are competent in dealing with the transmission of tuberculosis, and persuasive approaches by close family members, those who are affected by tuberculosis, gradually understand and understand its importance. healthy living culture, thus encouraging their awareness to be positive, and gradually raising their awareness to care, behave, in harmony with a healthy living culture.

Giddens (2010), argues that the formation of the social structure of society can be divided into three, namely signification, dominance and legitimacy. Signification structures are institutional arrangements that involve symbolic arrangements or ways of discourse in society. Domination is an institutional arrangement that involves political and economic institutions. While the legitimacy structure concerns the institutional arrangements in the realm of legal institutions.

Signification is related to empirical symbols, empirical phenomena, speech, gestures by individual groups of people about tuberculosis. Based on the results of interviews in the field, these empirical symbols include; health, environmental hygiene, support from family and neighbors in helping the treatment of tuberculosis patients. The environmental conditions of the people of Semarang City who are sick with tuberculosis are different, some live in a relatively clean environment and some live in a dirty environment. Likewise with medical support for family members who are sick with tuberculosis, the findings in the field are that there are no patients who are neglected by their families. Everyone who is sick with tuberculosis gets good support and motivation from the family. One of the factors that is still a question for the community is that they are confused about where they got the tuberculosis disease from. This can happen when the public lacks information about tuberculosis.

Domination is an aspect related to political and economic institutions in the problem of tuberculosis in society. In this case, it involves three aspects, namely 1) the socio-cultural community in assessing the presence of tuberculosis. The condition of the people of Semarang City in general already know about tuberculosis, but the symptoms of the illness do not know in detail. Some people know about the existence of tuberculosis because in the past a family member has been sick. 2) The role of the state or health service agencies in providing education or explanation about tuberculosis to the public objectively. Counseling

Supriyanto, S., Masrukhi, M., Suyahmo, S., \& Astuti, T. M. P. (2022). Healthy living culture as management of tuberculosis. International Journal of Health Sciences, 6(1), 137-148. https://doi.org/10.53730/ijhs.v6n1.3527 
activities about tuberculosis in the city of Semarang have been carried out, but the intensity is not too frequent, so that not all citizens get this information. Counseling activities are usually carried out by puskesmas officers and mothers of health cadres. 3) Individuals who are sick with tuberculosis are subjective or objective. People with tuberculosis are open and admit their illness or be secretive. The condition of people with tuberculosis in the city of Semarang is partly open and some are closed.

Legitimacy is a form of legal institution that can provide sanctions for violators. Aspects concerning legitimacy are rules, normative and moral. Based on the results of the research, many violations were found related to the healthy living culture in the community, for example; when coughing the mouth is not closed, staying up late, the environment is not clean, consuming liquor, and smoking. This form of violation requires persuasive warnings, so that people can avoid tuberculosis.

In addition, it is also necessary to seek an approach in the context of education that is able to change people's perceptions of tuberculosis to be positive, not demeaning and not hating people with tuberculosis. However, the community can help people who are sick with tuberculosis by taking a persuasive approach to raise awareness of people with tuberculosis so that they want to seek treatment and behave in a healthy life.

Furthermore, legitimacy is also related to policies issued by the state in making regulations for the handling of tuberculosis and to guarantee the right of the community to obtain health rights. The current regulations still focus on health services regarding tuberculosis by puskesmas.

Rules for individuals with tuberculosis. The people of the city of Semarang should avoid unhealthy living habits such as; smoking, staying up late, dirty environment, consuming liquor and not getting used to wearing masks. Apart from that, there are also regulations regarding education and counseling activities carried out by health cadres. Meanwhile, regulations for tuberculosis patients who are absent from treatment and do not practice a healthy lifestyle do not yet exist. For more details, the schema about the healthy living culture of the people of Semarang City can be seen in Figure 3.

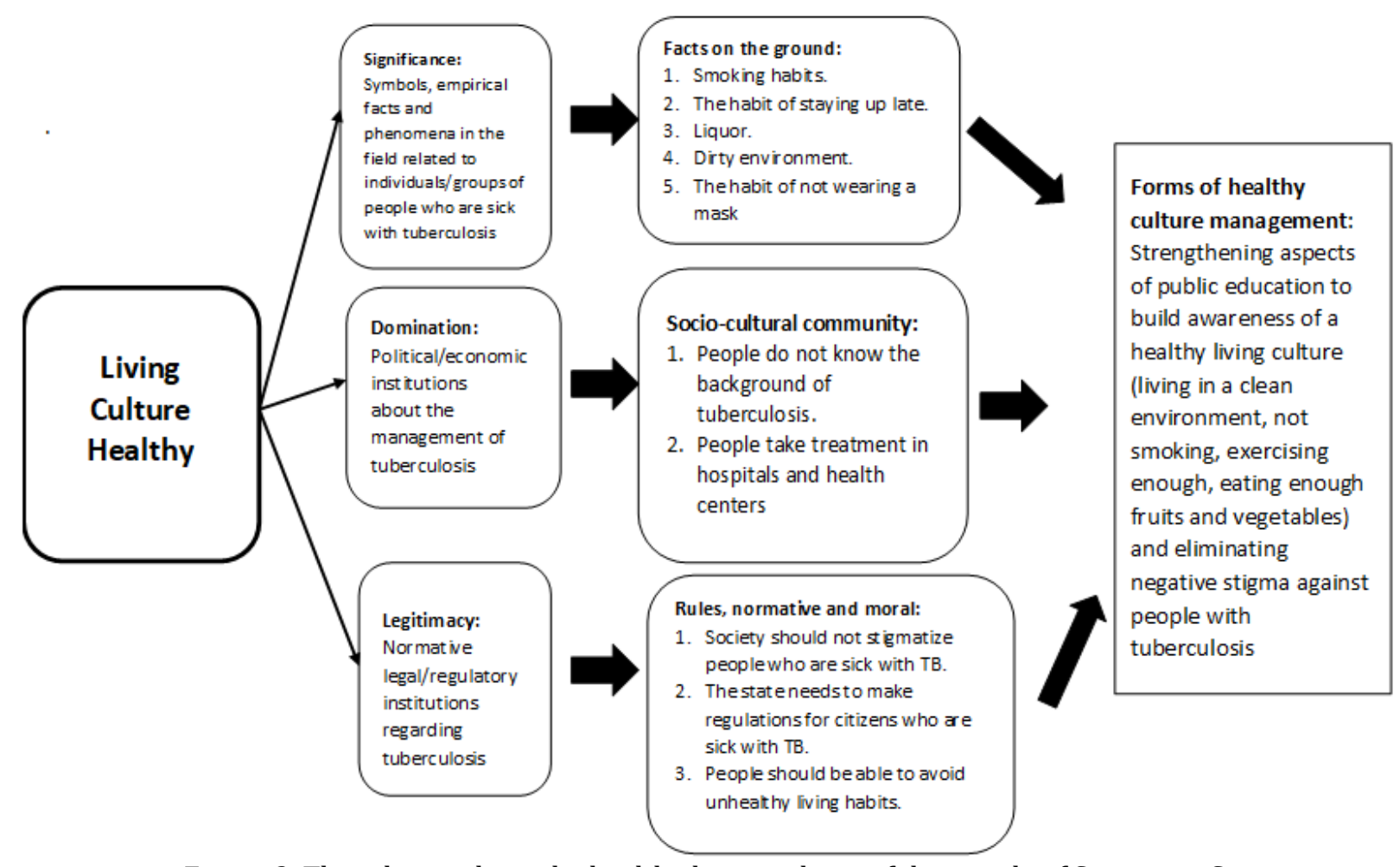

Figure 3. The schema about the healthy living culture of the people of Semarang City 


\section{Conclusion}

The culture of healthy living carried out by the people of Semarang City is carried out in the form of 1). Implement healthy living behaviors such as; live in a clean environment, do not smoke, exercise enough, eat enough fruit and vegetables. 2). Availability of health facilities that are professional and easily accessible to the public such as hospitals and health centers 3). Remove the negative stigma against people who are sick with tuberculosis.

Acknowledgments

We would thank to Universitas Negeri Semarang for supporting the completion of this article.

Supriyanto, S., Masrukhi, M., Suyahmo, S., \& Astuti, T. M. P. (2022). Healthy living culture as management of tuberculosis. International Journal of Health Sciences, 6(1), 137-148. https://doi.org/10.53730/ijhs.v6n1.3527 


\section{References}

Astuti, E. P., \& Ardianto, F. (2010). Hubungan tingkat pengetahuan dan sikap dengan perilaku pencegahan penularan tuberkulosis paru pada keluarga. Jurnal Penelitian STIKES Kediri, 3(1), 19-28.

Astuti, T. M. P. (2013). Penghargaan Sosial Semu dan Liminalitas Perempuan Migran.

Barr, R. G., Celli, B. R., Mannino, D. M., Petty, T., Rennard, S. I., Sciurba, F. C., ... \& Turino, G. M. (2009). Comorbidities, patient knowledge, and disease management in a national sample of patients with COPD. The American journal of medicine, 122(4), 348-355. https://doi.org/10.1016/j.amjmed.2008.09.042

Benjamini, Y., Drai, D., Elmer, G., Kafkafi, N., \& Golani, I. (2001). Controlling the false discovery rate in behavior genetics research. Behavioural brain research, 125(1-2), 279-284. https://doi.org/10.1016/S01664328(01)00297-2

Bhardwaj, A., Bhartiya, D., Kumar, N., Scaria, V., \& Open Source Drug Discovery Consortium. (2009). TBrowse: an integrative genomics map of Mycobacterium tuberculosis. Tuberculosis, 89(5), 386-387. https://doi.org/10.1016/j.tube.2009.07.005

Carter, A. S., Wagmiller, R. J., Gray, S. A., McCarthy, K. J., Horwitz, S. M., \& Briggs-Gowan, M. J. (2010). Prevalence of DSM-IV disorder in a representative, healthy birth cohort at school entry: Sociodemographic risks and social adaptation. Journal of the American Academy of Child \& Adolescent Psychiatry, 49(7), 686-698. https://doi.org/10.1016/j.jaac.2010.03.018

Chaika, O., Chahrak, N., Zhumbei, M., Apelt, H., Kopchak, L., \& Litvinova, A. (2021). Pedagogical framework for poly multicultural education of foreign language students seeking a degree in teaching. International Journal of Health Sciences, 5(3), 605-616. https://doi.org/10.53730/ijhs.v5n3.2618

Creswell, J. W. (2010). Research design pendekatan kualitatif, kuantitatif, dan mixed. Yogyakarta: pustaka pelajar.

Dantzer, R., \& Kelley, K. W. (2007). Twenty years of research on cytokine-induced sickness behavior. Brain, behavior, and immunity, 21(2), 153-160. https://doi.org/10.1016/j.bbi.2006.09.006

Exposto, L. A. S., \& Januraga, P. P. (2021). Domestic waste characteristics and the management systematic review. International Journal of Health \& Medical Sciences, 4(2), 253-259.

Fialkowski, M. K., DeBaryshe, B., Bersamin, A., Nigg, C., Guerrero, R. L., Rojas, G., ... \& CHL Team. (2014). A community engagement process identifies environmental priorities to prevent early childhood obesity: the children's healthy living (CHL) program for remote underserved populations in the US affiliated pacific islands, Hawaii and Alaska. Maternal and child health journal, 18(10), 2261-2274.

Foster, G. M., \& Anderson, B. G. (2006). Antropologi Kesehatan Foster/Anderson (Cetakan 1). Universitas Indonesia (UI-Press).

Frieden, T. R., \& Driver, C. R. (2003). Tuberculosis control: past 10 years and future progress. Tuberculosis, 83(1-3), 82-85. https://doi.org/10.1016/S1472-9792(02)00060-4

Geertz, C. (1973). The interpretation of cultures (Vol. 5019). Basic books.

Giddens, A. (2010). The rise and fall of New Labour. New Perspectives Quarterly, 27(3), 32-37.

Hussin, D. A., Samah, M. A. A., Suhaimi, A. A., \& Kamarudin, M. K. A. (2021). A study on knowledge, attitude and practice of COVID-19 pandemic among the residents. International Journal of Health Sciences, 5(2), 177188. https://doi.org/10.29332/ijhs.v5n2.1378

Karso, O. S., \& Wibawa, A. P. (2017). Research On Government Programs" Healthy Living Community Movement"(GERMAS) In Bali Using Critical Discourse Analysis. International Journal of ResearchGranthaalayah, 5(6), 82-91.

Kelley, K. W., Bluthé, R. M., Dantzer, R., Zhou, J. H., Shen, W. H., Johnson, R. W., \& Broussard, S. R. (2003). Cytokine-induced sickness behavior. Brain, behavior, and immunity, 17(1), 112-118. https://doi.org/10.1016/S0889-1591(02)00077-6

Koentjaraningrat, K. (2009). Pengantar Ilmu Antropologi, Edisi Revisi PT. Rineka Cipta: Jakarta.

Kroeber, A. L., \& Kluckhohn, C. (1952). Culture: A critical review of concepts and definitions. Papers. Peabody Museum of Archaeology \& Ethnology, Harvard University.

Lee, J. C., Muller, C. H., Rothman, I., Agnew, K. J., Eschenbach, D., Ciol, M. A., ... \& Berger, R. E. (2003). Prostate biopsy culture findings of men with chronic pelvic pain syndrome do not differ from those of healthy controls. The Journal of urology, 169(2), 584-588. https://doi.org/10.1016/S0022-5347(05)63958-4

Linton, R. (1936). The Study of Man. 499. Appleton-Century-Crofts-,Inc 
Maher, D. (2003). The role of the community in the control of tuberculosis. Tuberculosis, 83(1-3), 177-182. https://doi.org/10.1016/S1472-9792(02)00066-5

Miles, M. B., Huberman, A. M., \& Saldana, J. (2014). Qualitative data analysis: A methods sourcebook.

Ofman, J. J., Badamgarav, E., Henning, J. M., Knight, K., Gano Jr, A. D., Levan, R. K., ... \& Weingarten, S. R. (2004). Does disease management improve clinical and economic outcomes in patients with chronic diseases? A systematic review. The American journal of medicine,117(3), 182-192. https://doi.org/10.1016/j.amjmed.2004.03.018

Permana, A. T., Suroto, N. S., Parenrengi, M. A., Bajamal, A. H., Lestari, P., \& Fauzi, A. A. (2022). Current update on stroke ischemic management: Stem cell as emerging therapy. International Journal of Health \& Medical Sciences, 5(1). https://doi.org/10.21744/ijhms.v5n1.1851

Radclife-Brown. (1940). On Social Structure A. R. Radcliffe-Brown. The Journal of the Royal Anthropological Institute of Great Britain and Ireland, Vol. 70, N.

Rodnyansky, D. V., Valeeva, G. F., Abramov, R. A., \& Makarov, I. N. (2021). Social determinants of human health: Quantitative and qualitative studies. International Journal of Health Sciences, 5(3), 649-660. https://doi.org/10.53730/ijhs.v5n3.2809

Saigal, C. S., Joyce, G., Timilsina, A. R., \& Urologic Diseases in America Project. (2005). Direct and indirect costs of nephrolithiasis in an employed population: opportunity for disease management?. Kidney international, 68(4), 1808-1814. https://doi.org/10.1111/j.1523-1755.2005.00599.x

Samovar, L. A., Porter, R. E., McDaniel, E. R., \& Roy, C. S. (2014). Intercultural communication: A reader. Cengage Learning.

Schubert, K. (2015). Building a culture of health: Promoting healthy relationships and reducing teen dating violence. Journal of Adolescent Health, 56(2), S3-S4. https://doi.org/10.1016/j.jadohealth.2014.11.015

Swidler, A. (1986). Culture in action: Symbols and strategies. American sociological review, 273-286.

Westwood, M. J., \& Barker, M. (1990). Academic achievement and social adaptation among international students: A comparison groups study of the peer-pairing program. International journal of intercultural relations, 14(2), 251-263. https://doi.org/10.1016/0147-1767(90)90008-K

White, L. A. (1959). The Concept of Culture, transl. by Lazareva, EM. Antologiia issledovanii kul'tury, 1, 17-48.

Widana, I.K., Sumetri, N.W., Sutapa, I.K., Suryasa, W. (2021). Anthropometric measures for better cardiovascular and musculoskeletal health. Computer Applications in Engineering Education, 29(3), 550561. https://doi.org/10.1002/cae.22202

World Health Organization. (1981). Development of indicators for monitoring progress towards health for all by the year 2000. World Health Organization.

Supriyanto, S., Masrukhi, M., Suyahmo, S., \& Astuti, T. M. P. (2022). Healthy living culture as management of tuberculosis. International Journal of Health Sciences, 6(1), 137-148. https://doi.org/10.53730/ijhs.v6n1.3527 


\section{Biography of Authors}

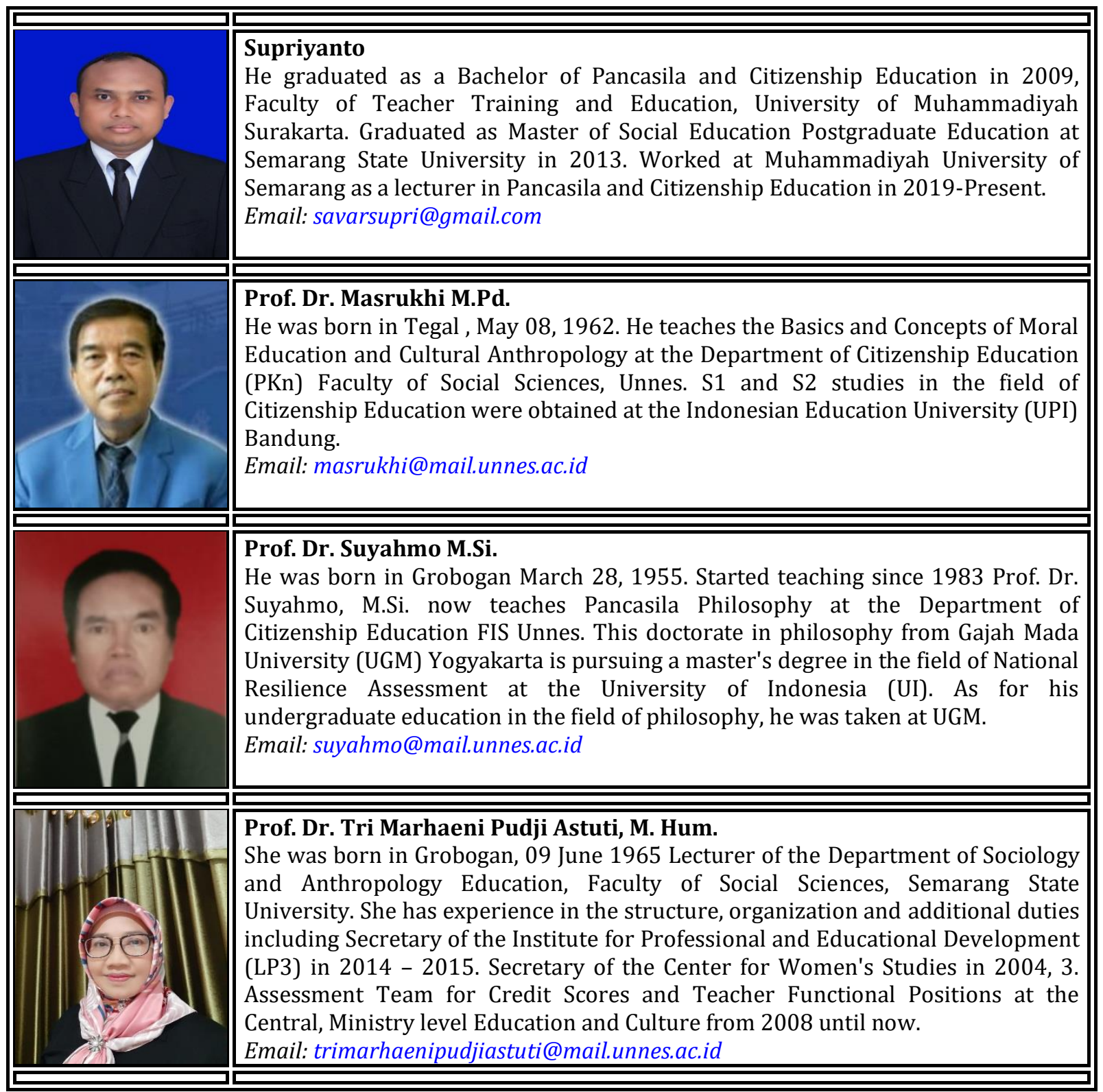

